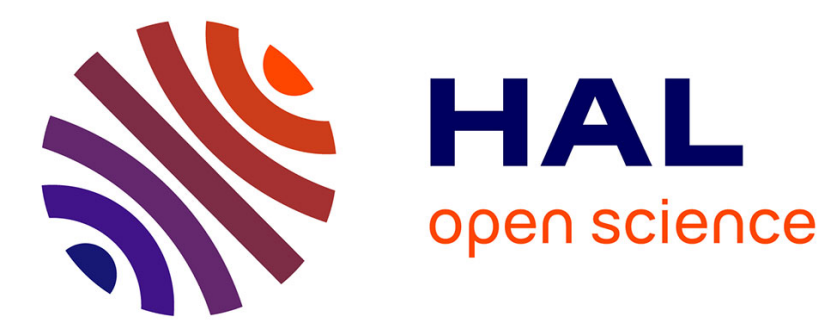

\title{
Water Vapor Adsorption/Desorption on Two Fully Characterized Commercial Activated Carbons
}

Christelle Miqueu, Frédéric Plantier, Kamila Marques Fernandes, Carine Malheiro, Bernard Delanghe

\section{- To cite this version:}

Christelle Miqueu, Frédéric Plantier, Kamila Marques Fernandes, Carine Malheiro, Bernard Delanghe. Water Vapor Adsorption/Desorption on Two Fully Characterized Commercial Activated Carbons. 13èmes Journéess d'études des Milieux Poreux 2016, Oct 2016, Anglet, France. hal-01394539

\author{
HAL Id: hal-01394539 \\ https://hal.science/hal-01394539
}

Submitted on 9 Nov 2016

HAL is a multi-disciplinary open access archive for the deposit and dissemination of scientific research documents, whether they are published or not. The documents may come from teaching and research institutions in France or abroad, or from public or private research centers.
L'archive ouverte pluridisciplinaire HAL, est destinée au dépôt et à la diffusion de documents scientifiques de niveau recherche, publiés ou non, émanant des établissements d'enseignement et de recherche français ou étrangers, des laboratoires publics ou privés. 


\section{Water Vapor Adsorption/Desorption on Two Fully Characterized Commercial Activated Carbons}

Christelle Miqueu $^{a}$, Frederic Plantier ${ }^{a}$, Kamila Marques Fernandes ${ }^{a}$, Carine Malheiro ${ }^{a}$, Bernard Delanghe ${ }^{b}$

${ }^{a}$ Laboratoire des Fluides Complexes et leurs Reservoirs, UMR 5150, Univ. Pan et Pays Adour, 64600, Anglet, France

${ }^{b}$ Univ Pau et Pays Adour, UFR Sciences et Techniques Côte Basque, 64600, Anglet, France

Keywords : microporous, activated carbon, water

\section{Introduction}

Activated carbons (ACs) are widely used as adsorbents for removing pollutants from streams in industrial processes because of their powerful and various adsorption properties. The presence of water in ACs is known to have an important negative impact both on the capacity and on the selectivity for the removal of organic or inorganic contaminants in the industrial ACs [1-3].

The adsorption mechanism of water on ACs is quite different from that of simpler fluids such as nitrogen or alkanes [4]. While these simple compounds (e.g. nitrogen, argon, methane) present most usually type I isotherms (IUPAC classification) on ACs, water adsorption isotherm is S-shape, similar to type IV or $\mathrm{V}$ depending on the density of active sites. The difference in these behaviours is classically assigned both to the weak water-carbon interactions and to the strong hydrogen bonds that lead to water clusters formation (see the two interesting reviews of water behaviour in porous carbons by Brennan et al. [5] and Mowla et al. $[6])$.

Several investigations have been carried out on the measurement and the understanding of water adsorption on graphitic microporous materials (e.g. AC, ACF, SWNT) [7-11], sometimes with a complete surface chemistry and pore structure analysis $[12,13]$. However, the experiments have always been performed at a unique temperature, close to the ambient one, except in the work of Ohba et al. [14] and Nastaj and Aleksandrzak [15]. In this work, the adsorption behaviour is analysed on a wide range of temperature thanks to new experiments and modelling.

\section{Methods}

\subsection{Experimental section}

In the present study, the adsorption/desorption of water vapor on two commercial microporous ACs is measured at three temperatures $(353,369$ and $386 \mathrm{~K}$ ) by means of a magnetic suspension balance, in order to investigate the influence of temperature on the adsorptive properties. The two ACs are fully characterized in terms of structural properties and surface activity. The difference in their Pore Size Distribution (PSD) - more or less extended - allows discussing the impact of PSD on water adsorption.

\subsection{Thermodynamic modelling}

Few years ago, Do and Do [16] developed a model (DD) able to explain the role of active sites and microscopic structure of AC in the adsorption of water. This model is based on a two-step mechanism: a water cluster formation on active sites followed by the penetration of the clusters into the micropores. Since its introduction, several modifications concerning the size of clusters or the adsorption on actives sites have been proposed for this model. In their critical review of analytic approaches for the modelling of water adsorption on carbons, Furmaniak et al. [17] have shown the efficiency of DD derived models on water adsorption on ACs. In the present study, we test the DD model and its two principal modifications $[18,19]$ on the experimental isotherms of the two ACs. 


\section{Results}

The effect of temperature is clearly shown on the adsorption/desorption hysteresis but is negligible on the total adsorptive capacity of the AC. The different textural properties (specific surface area, pore volume and pore size distribution) of the two ACs have an evident impact on both the slope of the isotherm corresponding to the adsorption in micropores and the total capacity of adsorption of the AC. The original DD equation and two of its modifications were used to model the measured isotherms. All the isotherms could only be well-fitted by the version of Do and Do model improved by Furmaniak et al. (HDD).

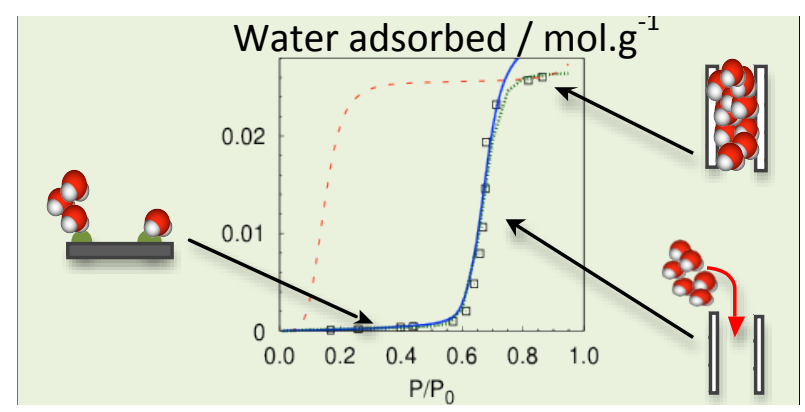

Figure 1: water vapor adsorption isotherm on Carboxen-1012® : $\square$ experiments, --- DD equation, - DDN equation, $\cdots$ HDD equation [19].

\section{References}

[1] Gong, R.; Keener, T. C.; J. Air Waste Manag. Assoc., 43, 864-872, (1993).

[2] Rodríguez-Mirasol, J.; Bedia, J.; Cordero, T.; Rodríguez, J.; Sep. Sci. Technol., 40, 3113-3135, (2005).

[3] Kaplan, D.; Nir, I.; Shmueli, L.; Carbon, 44, 3247-3254, (2006).

[4] Ohba, T.; Kanoh, H.; Kaneko, K.; J. Am. Chem. Soc., 126, 1560-1562, (2004).

[5] Brennan, J. K.; Bandosz, T. J.; Thomson, K. T.; Gubbins, K. E.; Colloids Surfaces A Physicochem. Eng. Asp., 187-188, 539-568, (2001).

[6] Mowla, D.; Do, D. D.; Kaneko, K. Adsorption of Water Vapor on Activated Carbon: A Brief Overview. Chem. Phys. Carbon., University of Queensland, Brisbane, QLD, Australia, 229-262, (2003).

[7] Mccallum, C. L.; Bandosz, T. J.; Mcgrother, S. C.; Mu, E. A., Langmuir, 15, 533-544, (1999).

[8] Sullivan, P. D.; Stone, B. R.; Hashisho, Z.; Rood, M. J.; Adsorption, 13, 173-189, (2007).

[9] Kim, P.; Zheng, Y.; Agnihotri, S.; Ind. Eng. Chem. Res., 47, 3170-3178, (2008).

[10] Wang, H.; Kleinhammes, A.; McNicholas, T. P.; Liu, J.; Wu, Y.; J. Phys. Chem. C, 118, 8474-8480, (2014).

[11] Furmaniak, S.; Wiśniewski, M.; Werengowska-Ciećwierz, K.; Terzyk, A. P.; Hata, K.; Gauden, P. A.; Kowalczyk, P.; Szybowicz, M.; J. Phys. Chem. C, 119, 2703-2715, (2015).

[12] Li, X.; Li, Z.; J. Chem. Eng. Data, 55, 5729-5732, (2010).

[13] Li, X.; Li, Z.; Sep. Purif. Technol., 85, 77-82, (2012).

[14] Ohba, T.; Kanoh, H.; Kaneko, K.; J. Phys. Chem. B, 108, 14964-14969, (2004).

[15] Nastaj, J.; Aleksandrzak, T.; J. Chem. Eng. Data, 58, 2629-2641, (2013).

[16] Do, D. D.; Do, H. D.; Carbon, 38, 767-773, (2000).

[17] Furmaniak, S.; Gauden, P. a; Terzyk, A. P.; Rychlicki, G.; Adv. Colloid Interface Sci., 137, 82-143, (2008).

[18] Neitsch, M.; Heschel, W.; Suckow, M.; Carbon, 39, 1437-1438, (2001).

[19] Furmaniak, S.; Gauden, P. a; Terzyk, A. P.; Rychlicki, G.; Wesołowski, R. P.; Kowalczyk, P.; J. Colloid Interface Sci., 290, 1-13, (2005). 